\title{
Carbohydrate-binding properties of a separately folding protein module from $\beta$-1,3-glucanase Lic16A of Clostridium thermocellum
}

Correspondence

Igor A. Dvortsov

dvortsov@img.ras.ru
Received 22 December 2008

Revised 24 March 2009

Accepted 3 April 2009

\author{
Igor A. Dvortsov, ${ }^{1}$ Natalia A. Lunina, ${ }^{1}$ Ludmila A. Chekanovskaya, ${ }^{1}$ \\ Wolfgang H. Schwarz, ${ }^{2}$ Vladimir V. Zverlov ${ }^{1,2}$ \\ and Galina A. Velikodvorskaya ${ }^{1}$ \\ ${ }^{1}$ Institute of Molecular Genetics RAS, 2 Kurchatov Square, 123182 Moscow, Russian Federation \\ ${ }^{2}$ Department of Microbiology, Technische Universität München, Am Hochanger 4, D-85350 \\ Freising-Weihenstephan, Germany
}

\section{INTRODUCTION}

Multimodular enzymes are frequently found in microorganisms that hydrolyse complex mixed carbohydrates (Coutinho \& Henrissat, 1999; Lynd et al., 2002). Microbial glycosyl hydrolases are often members of this class of proteins (Bayer et al., 2000; Schwarz et al., 2004). The modules of such enzymes are linked by flexible spacers and represent independently folded structures (Boraston et al., 1999; Carrard et al., 2000). It is possible to separate such a module from a protein without affecting its properties. Carbohydrate-binding modules (CBMs) are the most numerous among non-catalytic modules. According to Boraston et al. (1999), the main functions of CBMs in a multimodular enzyme are as follows. (i) Substrate proximity - the CBM binds to a polysaccharide, thus putting the catalytic module in close proximity to its substrate. (ii) Carbohydrate targeting - a CBM having an affinity to the same polysaccharide as the catalytic module can increase its efficiency; this function is more important

Abbreviation: $\mathrm{CBM}$, carbohydrate-binding module.

A supplementary table listing homologues of the CBMX module of Lic16A of C. thermocellum is available with the online version of this paper. for micro-organisms that use complex carbohydrates. (iii) Disruptive function - some CBMs dissolve the crystal structure of a microfibril to make it more accessible to the catalytic module. (iv) Enzyme stabilization - the presence of auxiliary modules stabilizes the enzyme structure and enhances its temperature resistance. (v) Activity modulation - the CBM affects the type and parameters of the catalytic module activity. In addition some CBMs are responsible for anchoring carbohydrate hydrolases to the surface of the bacterial cell (Ezer et al., 2008). According to the classification presented in the CAZy database (http:// www.cazy.org/fam/acc_CBM.html), the presently known CBMs are classified into 53 families (Cantarel et al., 2009).

Clostridium thermocellum is a moderately thermophilic anaerobic bacterium commonly found in soil, self-heated rotting biomass and hot springs (Johnson et al., 1982; Chuvil'skaya et al., 1986; Belaich et al., 1997). This bacterium produces multienzyme complexes (cellulosomes) specialized in cellulose degradation (Bayer \& Lamed, 1986). Most of the glycosyl hydrolases of $C$. thermocellum are parts of the cellulosome (Zverlov et al., 2005). However, there are exoenzymes that do not belong to this complex (Schwarz et al., 2004; Berger et al., 2007). One of these non-cellulosomal enzymes is laminarinase 
Lic16A (GenBank accession no. CAC27412), with a molecular mass of $147 \mathrm{kDa}$. The structure and some properties of Lic16A have been investigated (Fuchs et al., 2003). Biochemically, Lic16A is characterized as a $1,3-\beta$-Dglucan glucanohydrolase (EC 3.2.1.73) or endo-1,3(4)glucanase (EC 3.2.1.6). It has a complex structure (see Fig. 1a) and shows high activity on polysaccharides with mixed $1,3-1,4-\beta$-linkages. It is composed of a leader peptide, a threefold repeat of a module homologous to proteins of the cell surface layer (SLH), the CBMX module, a GH16 catalytic module and a fourfold repeat of a CBM belonging to the CBM4A subfamily (Zverlov et al., 2001).

Here the properties of the separated CBMX and of Lic16A deletion derivatives were investigated, as well as the influence of CBMX on the enzymic features of the catalytic module. We have demonstrated that CBMX is a separately folding protein unit which contains a hitherto unknown carbohydrate-binding module.

\section{METHODS}

Recombinant DNA techniques and protein purification. DNA preparation, cloning, restriction and PCR were carried out by standard procedures (Sambrook et al., 1989) and in accordance with recommendations of the manufacturers. Chromosomal DNA of the C. thermocellum F7 strain (Chuvil'skaya et al., 1986) was used as PCR template. The oligonucleotide primers used for PCR amplifications are specified in Table 1. The resulting DNA fragments were inserted into the pQE32 expression vector (Qiagen), and their sequences were verified by sequencing double-stranded plasmid DNA on both strands by using ABI BigDye Terminator v. 3.1 reagents and an ABI Prism 3100-Avant genetic analyser (Applied Biosystems). For cloning and expression, Escherichia coli XL-1 Blue was used. E. coli cells were grown at $37{ }^{\circ} \mathrm{C}$ in Luria-Bertani broth (LB) medium supplemented with necessary antibiotics. E. coli XL1 Blue cells carrying recombinant
Table 1. Oligonucleotide primers used in this study

\begin{tabular}{|ll|}
\hline Construct & \multicolumn{1}{c|}{ Sequence $\left(\mathbf{5}^{\prime}-\mathbf{3}^{\prime}\right)$} \\
\hline LicA-full & for: ctaatcctggatccaccatgaatccgaatgaag \\
& rev: caaaaccgaagctttagatagatctgccgtcc \\
LicA-xcat & for: ccaccaggatccgccggaaacgctctgattaacacc \\
& rev: ccaccaggatccgccggaaacgctctgattaacacc \\
LicA-catcbd & for: gggtctagagtggcgtctggtttggagcg \\
& rev: gggtctagagttgccggaaagaagcggagg \\
LicA-cat & for: gggtctagagtggcgtctggtttggagcg \\
& rev: ggggatccgtcctcaagaggctctctt \\
CBMX & for: caagtcggatccacaataaaaattctgaat \\
& rev: aatgaagagtggcgttaaaagcttgaataa \\
\hline
\end{tabular}

plasmids (pQE32::LicA-full, pQE32:: LicA-xcat, pQE32:: LicA-cat, pQE32:: LicA-catcbd) (Fig. 1b) and a helper plasmid pACYC-RIL, containing IleX and ArgU tRNA genes, which code for rare tRNAs in E. coli (Stratagene), were grown in LB medium supplemented with ampicillin $\left(100 \mathrm{mg}^{-1}\right)$ and chloramphenicol $\left(50 \mathrm{mg} \mathrm{l}^{-1}\right)$, collected by centrifugation, washed twice in $20 \mathrm{mM}$ Tris/ $\mathrm{HCl}, \mathrm{pH} \mathrm{8.0,} \mathrm{and}$ sonicated on ice to obtain crude cell extract. Proteins were purified on Ni-NTA-agarose as recommended by the manufacturer. The purity and molecular mass of protein fractions were verified by SDS-PAGE (Laemmli, 1970).

Enzyme assays. Enzyme solution aliquots in standard assays were incubated in a phosphate/citrate buffer $(50 \mathrm{mM})$ at various $\mathrm{pH}$ values and temperatures with polysaccharides in concentrations of $0.05-$ $0.5 \%(\mathrm{w} / \mathrm{v})$. The reducing sugars released from polymeric substrates were detected by the 3,5-dinitrosalicylic acid method (Wood \& Bhat, 1988). One unit of enzyme (U) liberates $1 \mu \mathrm{mol}$ glucose equivalent per minute under standard conditions. All tests were performed in triplicate, and the coefficients of variation (ratio of the standard deviation to the mean) were less than $10 \%$. Specific activities and Michaelis constants were calculated using the Microcal Origin 7.5
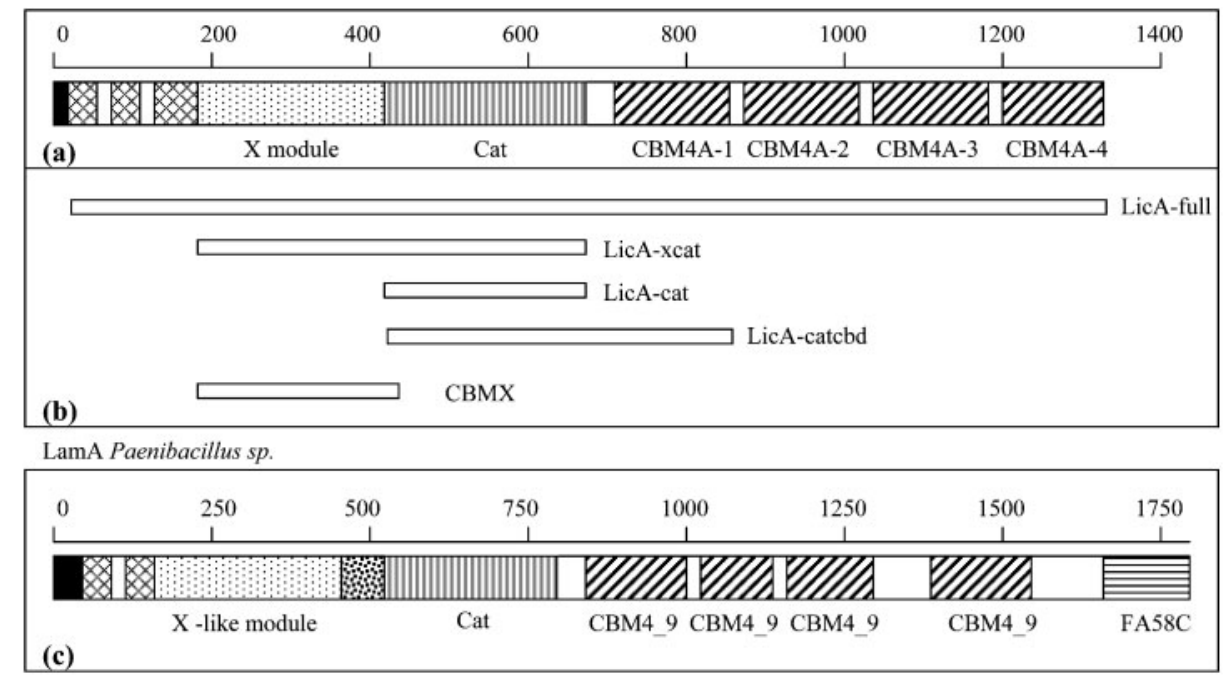

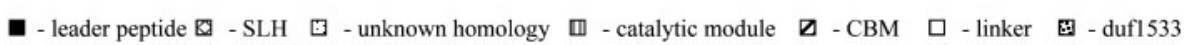

Fig. 1. (a) Multimodular structure of Lic16A from C. thermocellum. (b) Deletion derivatives of Lic16A. (c) Multimodular structure of LamA from Paenibacillus sp. 
software, from the reaction curves at the optimum temperature and $\mathrm{pH}$ values.

Binding to soluble carbohydrates. This was analysed using the affinity electrophoresis technique (Tomme et al., 1996). Native polyacrylamide gels $(10 \%)$, with or without soluble substrates $\left(1 \mathrm{mg} \cdot \mathrm{ml}^{-1}\right)$ added prior to polymerization, were prepared separately and run in parallel at $4{ }^{\circ} \mathrm{C}$. Bovine serum albumin was used as a negative control. Protein bands were visualized by staining with Coomassie brilliant blue R-250.

Binding of proteins to insoluble carbohydrates. This was investigated as described by Carvalho et al. (2004). Proteins in $50 \mathrm{mM}$ Tris/ $\mathrm{HCl}, \mathrm{pH} 7.0,0.05 \%$ Tween 20 buffer solutions were incubated with insoluble polysaccharides for $3 \mathrm{~h}$ at $4{ }^{\circ} \mathrm{C}$ with stirring. The samples were then centrifuged, and the supernatant was removed for measurement of the protein concentration by the Bradford assay (Bradford, 1976). The pellets were washed three times with the same buffer, dissolved in the sample buffer, boiled for $10 \mathrm{~min}$ and then loaded onto a gel for electrophoresis. The amount of bound protein was calculated as the difference between the added amount and the remaining amount in the supernatant. Binding constants and target binding capacity were computed using the single binding site model from the equation

$[B]=\frac{\left[N_{0}\right][F]}{\frac{1}{K_{a}}+[F]}$

where $\left[N_{0}\right]$ is the concentration of the carbohydrate-binding sites, $[F]$ the concentration of free (unbound) protein, $[B]$ the concentration of bound protein, and $K_{\mathrm{a}}$ the binding constant $\left(\mathrm{M}^{-1}\right)$.

Protein melting. Protein melting curves in $50 \mathrm{mM}$ MES buffer, $\mathrm{pH}$ 6.0, were determined spectrophotometrically by measuring UV absorption of protein solutions at different temperatures, by using the Agilent 8453 UV-visible Spectroscopy system, with the thermostatic cell Agilent 89090A Peltier temperature controller (Agilent). Measurements were done at $280 \mathrm{~nm}$ (tryptophan absorption maximum) and $1{ }^{\circ} \mathrm{C}$ steps within a temperature range of $25-90{ }^{\circ} \mathrm{C}$. At each step the solutions were allowed to reach equilibrium. Measurements were repeated three to five times to achieve a $5 \%$ margin of error. Melting points were determined using the Agilent ChemStation software.

Polysaccharides. Activity and binding of Lic16A and its deletion derivatives were evaluated on lichenan, laminarin, Avicel CF1 and carboxymethylcellulose (Sigma-Aldrich), as well as on chitin, chitosan, xylan, bacterial crystalline cellulose from Sigma-Aldrich, pachyman from Megazym and pustulan from Roth. Phosphoric acid swollen cellulose was prepared from Avicel CF1 by the method of Wood (1988). Insoluble $\beta$-glucan from the yeast cell wall of Saccharomyces cerevisiae was prepared according to Bacon et al. (1969).

\section{RESULTS}

\section{Lic16A primary structure and construction of truncated proteins}

Fig. 1(a) illustrates the modular organization of the enzyme Lic16A (Fuchs et al., 2003). A fragment of about $25 \mathrm{kDa}$, corresponding to amino acid residues 191-426 of this sequence, is denoted as the $\mathrm{X}$ module or CBMX. Amino acid sequences containing areas homologous to CBMX have been identified by BLAST (http://blast.ncbi.nlm.nih.
gov/Blast.cgi) (see Supplementary Table S1, available with the online version of this paper). The most homologous genes code for bacterial proteins which contain N-terminal SLH modules, some of them combined with a putative catalytic module of family GH16. The only other related enzyme which has been experimentally characterized is the endo-1,3- $\beta$-glucanase LamA from Paenibacillus sp. (GenBank accession no. ABJ15796). It shows $65 \%$ sequence similarity in the CBMX-encoding portion of the gene. This enzyme degrades $\beta$-1,3-linkages in glucans, e.g. in laminarin and curdlan (Hong \& Meng, 2003). It has a multimodular structure remarkably similar to Lic16A (see Fig. 1a, c). The flanking sequences of the CBMX module of Lic16A are enriched for proline and threonine residues. Similar sequences often serve as linkers separating modules in multimodular proteins (Gilkes et al., 1991; Howard et al., 2004). To characterize the function of the $X$ module, five deletion mutants of Lic16A were constructed using PCR (Fig. 1b). The recombinant proteins were produced in E. coli cells with a $\mathrm{His}_{6}$-tag sequence upon induction, allowing for onestep purification from the cell extracts. All the recombinant proteins were devoid of a leader peptide. LicA-full represents the intact protein $(144 \mathrm{kDa}), \mathrm{CBMX}$ the isolated X module $(25 \mathrm{kDa}), \mathrm{LicA}-\mathrm{xcat}$ a tandem of the $\mathrm{X}$ and catalytic module $(53 \mathrm{kDa})$, LicA-cat the separate catalytic module $(34 \mathrm{kDa})$, and LicA-catcbd a tandem of CBM4A-1 and the catalytic module $(48 \mathrm{kDa})$. The recombinant proteins were purified for further characterization.

\section{Biochemical characterization of deletion mutants}

The ability of Lic16A to degrade various $\beta$-glucans has been demonstrated previously (Fuchs et al., 2003). Lic16A hydrolyses substrates containing $\beta-1,3$ - and mixed $\beta-1,3-$ 1,4 -linkages and has the largest activity on lichenan. Here, we investigated the activity of the deletion derivatives on lichenan, laminarin and a number of insoluble substrates (Table 2). A comparison of Michaelis constants for soluble substrates shows that the modular composition of the deletion derivatives predominantly affects their affinity for carbohydrates, whereas their specific activity per molecule $\mathrm{A}_{\mathrm{a}}\left(\mathrm{U} \mu \mathrm{mol}^{-1}\right)$ remains practically unchanged (Table 2$)$.

The temperature and $\mathrm{pH}$ optima for LicA-full and LicAxcat coincided $\left(70{ }^{\circ} \mathrm{C}\right.$ and 6.0 respectively) but differed from those for LicA-cat and LicA-catcbd, not containing CBMX ( $60{ }^{\circ} \mathrm{C}$ and 6.5 respectively). The half-inactivation times of LicA-full, LicA-xcat, LicA-cat and LicA-catcbd at $70{ }^{\circ} \mathrm{C}$ were found to be $40,30,20$ and 20 min respectively (data not shown).

The effect of various additives on the activity of proteins on lichenan was investigated. EDTA $(5 \mathrm{mM}), \mathrm{Mg}^{2+}(2 \mathrm{mM})$ and $10 \%$ ethanol did not have appreciable influence on the constructs. A 1.5-2-fold activity increase occurred for $2 \%$ glycerol and $2 \mathrm{mM} \beta$-mercaptoethanol. However, $2 \mathrm{mM}$ $\mathrm{Ca}^{2+}$ and $10 \mathrm{mM}$ SDS stimulated only those polypeptides that had the X module in their structure, increasing their activity 1.5 -fold (data not shown). 
Table 2. Enzyme activities of constructs on various substrates

$\mathrm{A}_{\mathrm{a}}$, enzyme activity $\left(\mathrm{U} \mu \mathrm{mol}^{-1}\right) ; K_{\mathrm{m}}$, Michaelis constant $\left(\mathrm{mg} \mathrm{ml}^{-1}\right)$; ND, not detectable.

\begin{tabular}{|lccccc|}
\hline Substrate & & LicA-full & LicA-xcat & LicA-cat & LicA-catcbd \\
\hline Lichenan & $\mathrm{A}_{\mathrm{a}}$ & 964 & 888 & 983 & 1020 \\
& $K_{\mathrm{m}}$ & 0.45 & 0.98 & 1.41 & 1.54 \\
Laminarin & $\mathrm{A}_{\mathrm{a}}$ & 61 & 91 & 111 & 103 \\
& $K_{\mathrm{m}}$ & 2.11 & 1.69 & 3.83 & 3.56 \\
Yeast cell wall $\beta$-glucan & $\mathrm{A}_{\mathrm{a}}$ & $\mathrm{ND}$ & 0.43 & 0.52 & 0.48 \\
Pachyman & $\mathrm{A}_{\mathrm{a}}$ & 0.43 & 0.23 & 0.32 & 5.5 \\
Pustulan & $\mathrm{A}_{\mathrm{a}}$ & $\mathrm{ND}$ & 0.12 & 0.17 & 5.5 \\
\hline
\end{tabular}

\section{Protein melting}

Enzyme assays with soluble substrates showed that an increase in enzyme affinity could be attributed to the presence of the X module (Table 2). To investigate whether the $\mathrm{X}$ module acts as an independent subunit or forms a complex with the catalytic module, the protein stability and the stabilizing effect of various additives was studied by UV spectroscopy (see Fig. 2). Melting of a protein module is a cooperative process (Branden \& Tooze, 1999; Dobson et al., 1994; Finkelstein \& Ptytsin, 2005). Cooperation results in a narrow melting peak, as in the isolated catalytic module LicA-cat, with a melting point of about $83{ }^{\circ} \mathrm{C}$ (Fig. 2a). LicA-catcbd includes two modules connected by a flexible linker and, in contrast to LicA-cat, gives two overlapping melting peaks with apparent melting points of 69 and $83{ }^{\circ} \mathrm{C}$ and a low-temperature small peak at $38{ }^{\circ} \mathrm{C}$. Considering the result for the LicA-cat module, it is reasonable to associate the peak at $69{ }^{\circ} \mathrm{C}$ with the melting of CBM4A-1. The peak at $38{ }^{\circ} \mathrm{C}$ may reflect the interaction of the catalytic module and CBM4A-1 at low temperatures far from the temperature optimum. The melting curve for LicA-xcat also contains three apparent melting peaks, at 40,
65 and $80{ }^{\circ} \mathrm{C}$ (Fig. 2a). Therefore, LicA-xcat seems to include two modules essentially melting independently.

Among all the additives tested, calcium had the greatest effect on the recombinant proteins (Fig. 2b). During the melting of LicA-xcat in the presence of $10 \mathrm{mM} \mathrm{CaCl}_{2}$, only two peaks were observed; the low-temperature peak disappeared, and the melting points of the CBMX and catalytic modules shifted (to 68 and $78{ }^{\circ} \mathrm{C}$ respectively). Calcium had no effect on the melting rate of LicA-cat and LicA-catcbd, although in the latter case the three characteristic melting points were shifted upward slightly (40, 72 and $81{ }^{\circ} \mathrm{C}$ from 38, 69 and $83^{\circ} \mathrm{C}$ ).

\section{Polysaccharide binding of the isolated $X$ module}

The isolated X module was prepared by PCR (Fig. 1b), cloning and expression in E. coli and affinity purification to homogeneity (designated CBMX). Its molecular mass of about $25 \mathrm{kDa}$ corresponded to the theoretically predicted value. Its binding property to various target ligands was studied qualitatively (Fig. 3) and quantitatively (Table 3). CBMX demonstrated the highest affinity to yeast cell wall

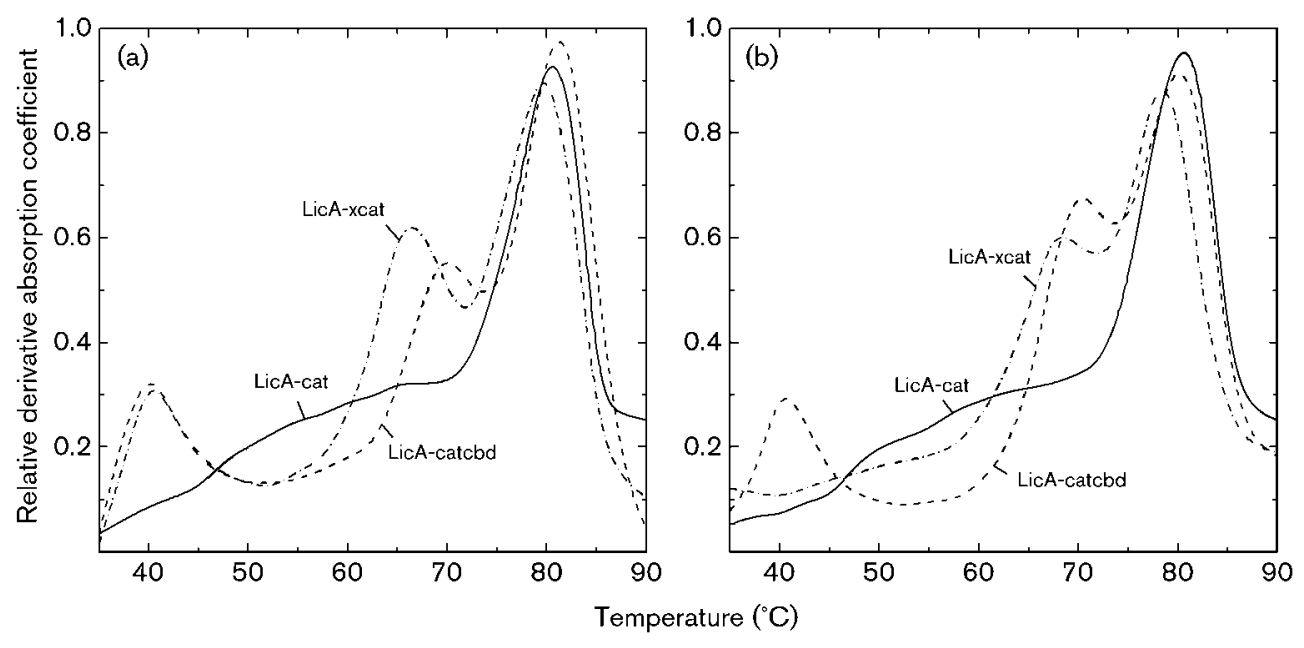

Fig. 2. Melting curves for Lic16A deletion fragments: (a) in the absence of calcium; (b) in the presence of $10 \mathrm{mM} \mathrm{CaCl}_{2}$. Absorbance was measured at $280 \mathrm{~nm}$. Derivative absorption coefficients were normalized relative to their maximum values. 

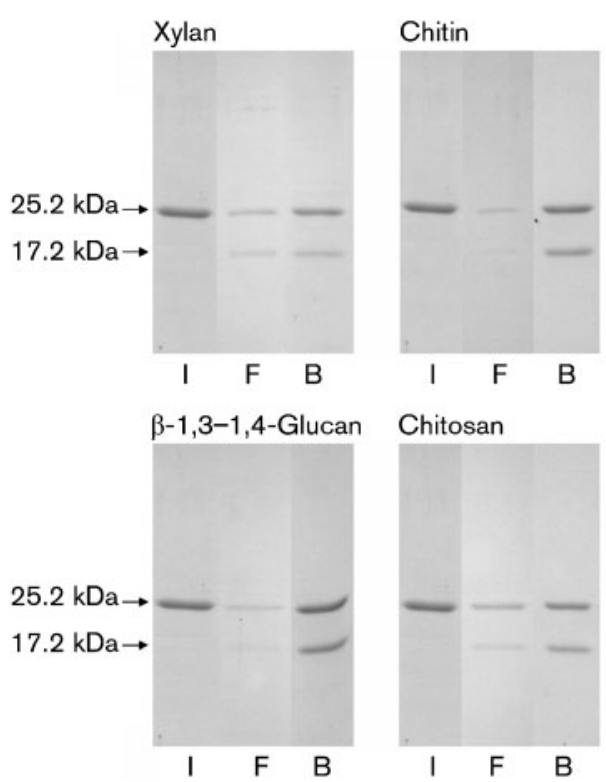
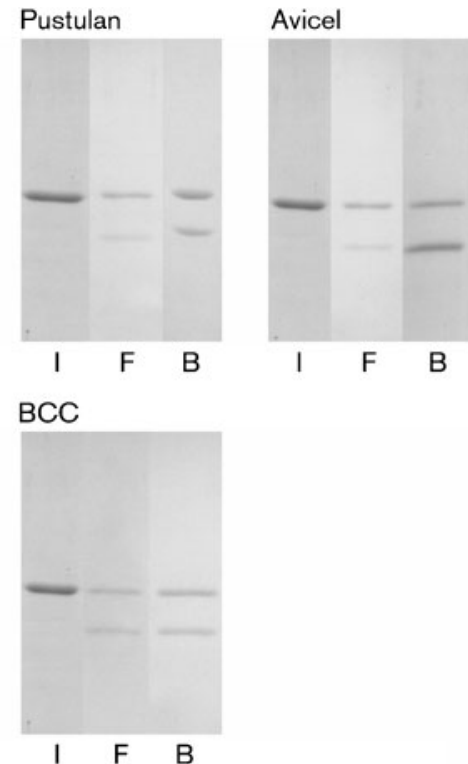

Fig. 3. Qualitative carbohydrate binding of CBMX. After the binding of CBMX to the insoluble polysaccharides and washing of unbound protein in $50 \mathrm{mM}$ Tris/ $\mathrm{HCl}, \mathrm{pH} 7.0$, $0.05 \%$ Tween 20 buffer solution, the bound protein was eluted by 10 min boiling in sample buffer. I, initial protein before binding; F, free protein in supernatant after binding; $B$, protein bound to polysaccharide after washing. The presence of two protein bands with molecular masses $\sim 25.2 \mathrm{kDa}$ and $\sim 17.2 \mathrm{kDa}$ was due to the degradation of CBMX during binding procedures and was discussed earlier (Fuchs et al., 2003). $\beta$-Glucan, glucan from yeast cell wall; BCC; bacterial crystalline cellulose. $\beta$-glucan, xylan and chitin, with the affinity to other polysaccharides being markedly lower. Calcium strongly stimulated chitin and chitosan binding of CBMX but decreased the affinity to yeast cell wall $\beta$-glucan. Binding of other polysaccharides was not significantly affected by the presence of calcium. CBMX did not bind to soluble target molecules like lichenan, laminarin and CMC (data not shown), even though lichenan and laminarin are the polysaccharides for which Lic16A has substantially higher activity.

\section{DISCUSSION}

Lic16A is an enzyme with unusually high activity on soluble substrates. The enzyme has a complex structure consisting of one catalytic and eight non-catalytic modules. It is not clear how the non-catalytic modules support the catalytic activity. The CBMX module adjoins the catalytic module. The isolated CBMX module was shown to bind a wide range of different insoluble polysaccharides, including xylan, yeast cell wall $\beta$-glucan and crystalline cellulose. It has the highest affinity to xylan and yeast cell wall $\beta$-glucan. High affinity to chitin and chitosan is dependent on the presence of calcium ions. A similar ability to bind such a wide range of heterogeneous polysaccharides is characteristic of carbohydrate-binding modules of family CBM37 (Ezer et al., 2008).

We have identified a number of proteins with high homology to CBMX (Supplementary Table S1). As none of the already known CBMs has significant homology to CBMX, the latter seems to contain a new family of CBMs (CBM54). The corresponding areas of the proteins listed in Supplementary Table S1 can also be postulated to have carbohydrate function. According to results from the retardation experiments, LicA-catcbd failed to bind the soluble target substances laminarin and lichenan, on which the catalytic module showed the highest activity. LicAcatcbd was slightly more active on insoluble substrates than the other constructs studied and deletion of CBMX led to a decrease in the affinity of Lic16A for soluble carbohydrates.

Table 3. Target binding capacity $\left(N_{0}\right)$ and binding constants $(K)$ for module CBMX

\begin{tabular}{|c|c|c|c|c|}
\hline \multirow[t]{2}{*}{ Polysaccharide target } & \multicolumn{2}{|c|}{ With calcium } & \multicolumn{2}{|c|}{ Without calcium } \\
\hline & $N_{0}\left(\mu \mathrm{mol} \mathrm{g}{ }^{-1}\right)$ & $K\left(\mathrm{M}^{-1}\right)$ & $N_{0}\left(\mu \mathrm{mol} \mathrm{g}^{-1}\right)$ & $K\left(\mathrm{M}^{-1}\right)$ \\
\hline Xylan & $34 \pm 1$ & $(5 \pm 1) \times 10^{4}$ & $14 \pm 1$ & $(3.1 \pm 0.5) \times 10^{4}$ \\
\hline Chitin & $48 \pm 1$ & $(3.3 \pm 0.7) \times 10^{5}$ & $10 \pm 0.3$ & $(1 \pm 0.1) \times 10^{3}$ \\
\hline Pustulan & $16 \pm 0.6$ & $(3.4 \pm 1) \times 10^{3}$ & $12 \pm 0.5$ & $(2.1 \pm 0.5) \times 10^{3}$ \\
\hline Avicel & $40 \pm 2$ & $(8.5 \pm 1.6) \times 10^{3}$ & $16 \pm 0.6$ & $(3.4 \pm 1) \times 10^{3}$ \\
\hline Yeast cell wall $\beta$-glucan & $18 \pm 0.5$ & $(5 \pm 0.5) \times 10^{4}$ & $18 \pm 0.3$ & $(1.4 \pm 0.2) \times 10^{5}$ \\
\hline Chitosan & $20 \pm 0.6$ & $(6.6 \pm 0.5) \times 10^{4}$ & $24 \pm 1$ & $21 \pm 5$ \\
\hline Bacterial crystalline cellulose & $16 \pm 0.6$ & $(2.8 \pm 0.6) \times 10^{3}$ & $14 \pm 0.6$ & $(3 \pm 0.6) \times 10^{3}$ \\
\hline
\end{tabular}




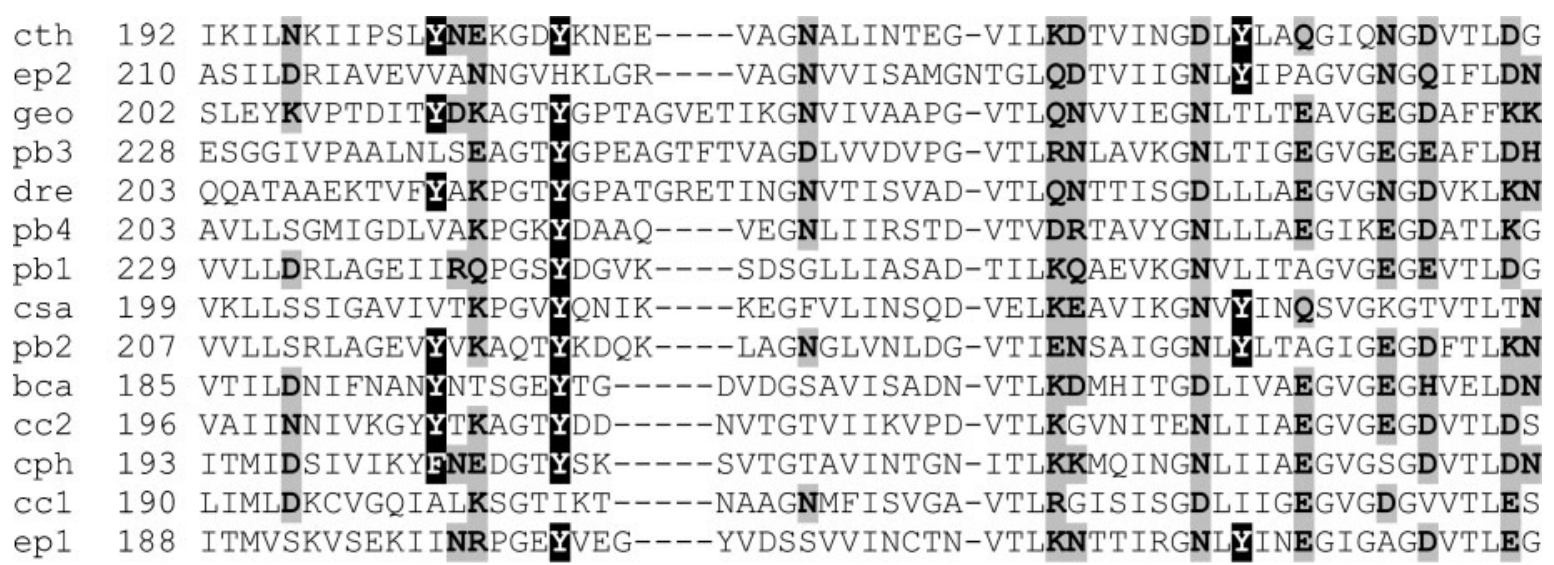

\begin{tabular}{|c|c|c|}
\hline cth & 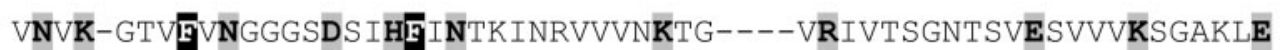 & \\
\hline ep2 & VEVR-GTVEFEGGXX---ILENTKIETLIVNNED----TTIKGNFKSEVEVADIRTAANID & 323 \\
\hline & VNVK-GTTTIQGGGANSVHFEDSVLVRV-SVDKQT-GTVRVVVVGESAIQHVVVHSPVKLE & \\
\hline & VKVS-GST互IRGGGVNSVHLDDSELGTV-VIEKKD-GKVRVVVSGTTVVEQMDVKSNASVE & \\
\hline & VKVS-GKTIIKGGGANSVTLEDCSLPNI-TVSKE--G-VRVVASGNTTVKVVRLESGATLV & \\
\hline & VTVT-GKTVIKGGGSHSVVFDGAKLKDV-LINKPG-GAVRVVFSNGTTADQVLIQHPTDFE & \\
\hline & LSAD-GTLY్YVNGGGSHSVHLRNAKVGKV-VVNKSG-GPVRVVLEGSSKVGEMSLETGAVVE & \\
\hline & VSIENGKLEVFGGGSNSVKLNNTKVKEVYVANMVS-EKVRLS IEGKSEVEHLIVIS & \\
\hline & TEVN-GTIEISGGGVHS I HLNNVHVPAI-IVDKKE-GPVRVIVDG-SEVGTMDLNSDTVLE & \\
\hline & VTVD-GRLLVRGGGANSIVIKGDSKITQVIIARQE-GKVRVAVEDGAQVSVVVVEEGSDDV & \\
\hline & VVRGGGENSIHITGSSNISNIKIEKNN-NKLRIVILDGNTVKEIEIAKGEEII & \\
\hline & IVRGGGKNSIHIIGSTKVANI IVDKKEKAPVSLKFSSSYESSSVTVINGELYL & \\
\hline & VKLA-GRLI IRGGGPNGVI I KNSQIGGNLIVEKSA-GNVYIRVVGSTTIKQAYLKSGCTIE & \\
\hline & VTVL-GTVEINGGGDKPIVLKX-CKMAEMVVDKYD-GNVNITGDA & \\
\hline
\end{tabular}

Fig. 4. Multiple alignment of the conserved region from CBMX (new family CBM54). Abbreviations: cth, licA C. thermocellum, CAC27412; ep2, Epulopiscium sp., ZP_02692123; geo, Geobacillus sp., Y412MC10, ZP_03036254; pb3, Paenibacillus sp. JDR-2, ZP_02846396; dre, Desulfotomaculum reducens Ml-1, YP001113692; pb4, Paenibacillus sp. JDR-2, ZP_02849476; pb1, Paenibacillus sp. CCRC17245, ABJ15796; csa, Caldicellulosiruptor saccharolyticus DSM 8903, YP_001181313; pb2, Paenibacillus sp. JDR-2, ZP_02847034; bca, Bacteroides capillosus ATCC 29799, ZP_02036105; cc2, Clostridium cellulolyticum H10, ZP_01575502; cph, Clostridium phytofermentans ISDg, YP_00158884; cc1, Clostridium cellulolyticum H10, ZP_01576976; ep1, Epulopiscium sp., ZP_02693375. Black boxes designate conserved residues potentially involved in sugar binding, grey boxes polar aromatic residues potentially involved in calcium binding.

According to the Lic16A primary structure analysis and to the melting experiments, CBMX is a separately folding module flanked by linker sequences. The temperature and $\mathrm{pH}$ optima, as well as the thermostability of the catalytic activity, of the LicA-cat module and the Cat-CBM4A-1 tandem of Lic16A coincided, suggesting that CBM4A-1 does not have any functions beyond binding polysaccharides. This conclusion was supported by the melting experiments. The binding module in Lic16A, CBM4A-1, belongs to the CBM4A family, members of which are known to bind soluble and partially also insoluble polysaccharides (Zverlov et al., 2001). Preliminary data show that CBM4A-1 might be specialized in binding insoluble polysaccharides. This observation and its influence on the catalytic activity of Lic16A will be the subject of further studies.
The activity of many cellulolytic enzymes of $C$. thermocellum increases in the presence of calcium ions (Lamed \& Bayer, 1988; Grepinet et al., 1988). The highest increase in the activity of recombinant truncated Lic16A proteins due to calcium stimulation was observed for constructs that contained CBMX. The analysis of LicA-xcat melting was in favour of a stabilizing effect of $\mathrm{Ca}^{2+}$ on CBMX. Addition of $\mathrm{Ca}^{2+}$ ions resulted in a more than 100-fold increase of the CBMX target binding capacity and binding constant on chitin and chitosan. Binding to the other polysaccharides studied here was not affected by calcium. CBMX probably contains more than one carbohydrate-binding site. This may also explain the wide target recognition spectrum of CBMX. In turn, chitin- and chitosanbinding centres of CBMX may include a $\mathrm{Ca}^{2+}$-binding site that affects the affinity to the target and provides 
stabilization of the module. The presence of CBMX in the constructs resulted in an increase in their temperature optimum, and the X-Cat tandem was determined to have a thermostability between that of Lic16A and the isolated catalytic module. Thus, it can be assumed that CBMX carries out a stabilizing function in Lic16A and moderates its activity.

A sequence alignment among the sequences from Supplementary Table S1 revealed a conserved core sequence in the $\mathrm{N}$-terminal part of the 14 sequences most homologous to the CBMX module (Fig. 4). This sequence covers 115 amino acid residues in CBMX and thus has the size of a typical CBM. However, the sequence is not homologous to hitherto known CBMs. Although none of the homologous sequences has been shown so far to have carbohydrate-binding capacity, it should be noted that a pattern of conserved aromatic amino acid residues can be identified (Fig. 4); these residues have been shown in other CBM families to be responsible for binding to target sugar residues (Xie et al., 2001; Boraston et al., 2004). Moreover, in the new family CBM54 some polar amino acid residues are more or less conserved which have a potential to be involved in target binding by hydrogen bonds (Notenboom et al., 2001; Xie et al., 2001; Pell et al., 2003) or in calcium ion binding (Bolam et al., 2004; Chauvaux et al., 1995; Jamal-Talabani et al., 2004).

It is interesting to note that in all 14 homologous proteins CBMX is located at the $\mathrm{N}$ terminus of the respective proteins, but preceded by another protein module, a duplicated SLH module which is involved in cell wall anchoring (Schwarz et al., 2004). The invariable juxtaposition of these two modules in the homologous proteins suggests a function of CBMX comparable to that of SLH in cell wall binding, similar to that of the CBM37 modules in ruminococci (Ezer et al., 2008). This function could be enhanced by the SLH module. However, the function of the conserved submodule CBM54 defined in Fig. 4 has to be investigated in other bacteria.

\section{NOTE ADDED IN PROOF}

After acceptance of this paper a subsequence of CBMX was added to the list of CBMs in the CAZy database as a new family, CBM54. The kind help of B. Henrissat in this matter is gratefully acknowledged.

\section{ACKNOWLEDGEMENTS}

This work was supported by the Russian Foundation for Basic Research (Project 06-04-48351a).

\section{REFERENCES}

Bacon, J. S. D., Farmer, V. C., Jones, D. \& Taylor, I. F. (1969). The glucan components of the cell wall of baker's yeast (Saccharomyces cerevisiae) considered in relation to its ultra-structure. Biochem J 114, $557-567$.
Bayer, E. A. \& Lamed, R. (1986). Ultrastructure of the cell surface cellulosome of Clostridium thermocellum. J Bacteriol 167, 828-836.

Bayer, E. A., Shoham, Y. \& Lamed, R. (2000). Cellulose decomposing prokaryotes and their enzyme systems. In The Prokaryotes: an Evolving Electronic Resource For The Microbiological Community, pp. 234-315. Edited by M. Dworkin, S. Falkow, E. Rosenberg, K. H. Schleifer \& E. Stackebrandt. New York: Springer-Verlag.

Belaich, J. P., Tardif, C., Belaich, A. \& Gaudin, C. (1997). The cellulolytic system of Clostridium cellulolyticum. J Biotechnol 57, 3-14.

Berger, E., Zhang, D., Zverlov, V. V. \& Schwarz, W. H. (2007). Two noncellulosomal cellulases of Clostridium thermocellum, Cel9I and Cel48Y, hydrolyse crystalline cellulose synergistically. FEMS Microbiol Lett 268, 194-201.

Bolam, D. N., Hefang, X., Pell, G., Hogg, D., Galbraith, G., Henrissat, B. \& Gilbert, H. J. (2004). X4 modules represent a new family of carbohydrate-binding modules that display novel properties. J Biol Chem 279, 22953-22963.

Boraston, A. B., McLean, B. W., Kormos, J. M., Alam, M., Gilkes, N. R., Haynes, C. A., Tomme, P., Kilburn, D. G. \& Warren, R. A. (1999). Carbohydrate-binding modules: diversity of structure and function. Recent Advances In Carbohydrate Bioengineering, pp. 202-211. Edited by H. J. Gilbert, B. Henrissat \& B. Svensson. Cambridge: Royal Society of Chemistry.

Boraston, A. B., Bolam, D. N., Gilbert, H. J. \& Davies, G. J. (2004). Carbohydrate-binding modules: fine tuning polysaccharide recognition. Biochem J 382, 769-781.

Bradford, M. M. (1976). A rapid and sensitive method for the quantitation of microgram quantities of protein utilizing the principle of protein-dye binding. Anal Biochem 72, 248-254.

Branden, K. \& Tooze, J. (1999). Introduction to Protein Structure, 2nd edn. New York: Garland Publishing.

Cantarel, B. L., Coutinho, P. M., Rancurel, C., Bernard, T., Lombard, V. \& Henrissat, B. (2009). The Carbohydrate-Active EnZymes database (CAZy): an expert resource for glycogenomics. Nucleic Acids Res 37 (Database issue), D233-D238. Epub 2008 Oct 5.

Carrard, G., Koivula, A., Soderlund, H. \& Beguin, P. (2000). Cellulose binding domains promote hydrolysis of different sites on crystalline cellulose. Proc Natl Acad Sci U S A 97, 10342-10347.

Carvalho, A. L., Goyal, A., Prates, J. A. M., Bolam, D. N., Hilbert, H. J., Pires, V. M. R., Ferreira, L. M. A., Planas, A., Romao, M. J. \& Fontes, C. M. G. A. (2004). The family 11 carbohydrate-binding module of Clostridium thermocellum Lic26A-Cel5E accommodates $\beta$-1,3- and $\beta$ 1,3-1,4-mixed linked glucans at a single binding site. J Biol Chem 279, 34785-34793.

Chauvaux, S., Souchon, H., Alzari, P. M., Chariot, P. \& Beguin, P. (1995). Structural and functional analysis of the metal-binding sites of Clostridium thermocellum endoglucanase CelD. J Biol Chem 270, 9757-9762.

Chuvil'skaya, N. A., Golovchenko, N. P., Belokopytov, B. F. \& Akimenko, V. K. (1986). Isolation, identification and some physiological properties of Clostridium thermocellum. Prikl Biokhim Mikrobiol 22, 800-805.

Coutinho, P. M. \& Henrissat, B. (1999). The modular structure of cellulases and other carbohydrate-active enzymes: an integrated database approach. In Genetics, Biochemistry and Ecology of Cellulose Degradation, pp. 15-23. Edited by K. Ohmiya, K. Hayashi, K. Sakka, Y. Kobayashi, S. Karita \& T. Kimura. Tokyo: Uni Publishers Co.

Dobson, C. M., Evans, P. A. \& Radsford, S. E. (1994). Understanding protein folding: the lysozyme story so far. Trends Biochem Sci 19, 3137.

Ezer, A., Matalon, E., Jindou, S., Borovok, I., Atamna, N., Yu, Z., Morrison, M., Bayer, E. A. \& Lamed, R. (2008). Cell-surface enzyme 
attachment is mediated by family-37 carbohydrate-binding modules, unique to Ruminococcus albus. J Bacteriol 190, 8220-8222.

Finkelstein, A. V. \& Ptytsin, O. B. (2005). The Physics of Protein. Moscow: Knizny Dom University.

Fuchs, K. P., Zverlov, V. V., Velikodvorskaya, G. A., Lottspeich, F. \& Schwarz, W. H. (2003). Lic16A of Clostridium thermocellum, a noncellulosomal, highly complex endo- $\beta$-1,3-glucanase bound to the outer cell surface. Microbiology 149, 1021-1031.

Gilkes, N. R., Henrissat, B., Kilburn, D. G., Miller, R. C. \& Warren, R. A. (1991). Domains in microbial beta-1, 4-glycanases: sequence conservation, function, and enzyme families. Microbiol Rev 55, 303-315.

Grepinet, O., Chebrou, M. C. \& Beguin, P. (1988). Nucleotide sequence and deletion analysis of the xylanase gene (xynZ) of Clostridium thermocellum. J Bacteriol 170, 4582-4588.

Hong, T. Y. \& Meng, M. (2003). Biochemical characterization and antifungal activity of an endo-1,3- $\beta$-glucanase of Paenibacillus sp. isolated from garden soil. Appl Microbiol Biotechnol 61, 472-478.

Howard, M. B., Ekborg, N. A., Taylor, L. E., Hutcheson, S. W. \& Weiner, R. M. (2004). Identification and analysis of polyserine linker domains in prokaryotic proteins with emphasis on the marine bacterium Microbulbifer degradans. Protein Sci 13, 1422-1425.

Jamal-Talabani, S., Boraston, A. B., Turkenburg, J. P., Tarbouriech, N., Ducros, V. M. \& Davies, G. J. (2004). Ab initio structure determination and functional characterization of CBM36; a new family of calcium-dependent carbohydrate binding modules. Structure 12, 1177-1187.

Johnson, E. A., Sakajoh, M., Halliwell, G., Madia, A. \& Demain, A. L. (1982). Saccharification of complex cellulosic substrates by the cellulase system from Clostridium thermocellum. Appl Environ Microbiol 43, 1125-1132.

Laemmli, U. K. (1970). Cleavage of structural proteins during the assembly of the head of bacteriophage T4. Nature 227, 680-685.

Lamed, R. \& Bayer, E. A. (1988). Characterization of a cellulosebinding cellulase-containing complex in Clostridium thermocellum. FEMS Symp 43, 101-116.

Lynd, L. R., Weimer, P. J., van Zyl, W. H. \& Pretorius, I. S. (2002). Microbial cellulose utilization: fundamentals and biotechnology. Microbiol Mol Biol Rev 66, 506-577.
Notenboom, V., Boraston, A. B., Chiu, P., Freelove, A. C., Kilburn, D. G. \& Rose, D. R. (2001). Recognition of cello-oligosaccharides by a family 17 carbohydrate-binding module: an X-ray crystallographic, thermodynamic and mutagenic study. J Mol Biol 314, 797-806.

Pell, G., Williamson, M. P., Walters, C., Du, H., Gilbert, H. J. \& Bolam, D. N. (2003). Importance of hydrophobic and polar residues in ligand binding in the family 15 carbohydrate-binding module from Cellvibrio japonicus Xyn10C. Biochemistry 42, 9316-9323.

Sambrook, J., Fritsch, E. F. \& Maniatis, T. (1989). Molecular Cloning: a Laboratory Manual, 2nd edn. Cold Spring Harbor, NY: Cold Spring Harbor Laboratory Press.

Schwarz, W. H., Zverlov, V. V. \& Bahl, H. (2004). Extracellular glycosyl hydrolases from clostridia. Adv Appl Microbiol 56, 215-261.

Tomme, P., Creagh, A. L., Kilburn, D. G. \& Hayens, C. A. (1996). Interaction of polysaccharides with the $\mathrm{N}$-terminal cellulose-binding domain of Cellulomonas fimi CenC. I. Binding specifity and calorimetric analysis. Biochemistry 35, 13885-13894.

Wood, T. M. (1988). Preparation of crystalline, amorphous and dyed cellulase substrates. Methods Enzymol 160, 19-25.

Wood, T. M. \& Bhat, K. M. (1988). Methods for measuring of cellulase activities. Methods Enzymol 160, 87-112.

Xie, H., Gilbert, H. J., Charnock, S. J., Davies, G. J., Williamson, M. P., Simpson, P. J., Raghothama, S., Fontes, C. M., Dias, F. M. \& other authors (2001). Clostridium thermocellum Xyn10B carbohydratebinding module 22-2: the role of conserved amino acids in ligand binding. Biochemistry 40, 9167-9176.

Zverlov, V. V., Volkov, I. Y., Velikodvorskaya, G. A. \& Schwarz, W. H. (2001). The binding pattern of two carbohydrate-binding modules of laminarinase Lam16A from Thermotoga neapolitana: differences in beta-glucan binding within family CBM4. Microbiology $147,621-629$.

Zverlov, V. V., Kellermann, J. \& Schwarz, W. H. (2005). Functional subgenomics of Clostridium thermocellum cellulosomal genes: identification of the major catalytic components in the extracellular complex and detection of three new enzymes. Proteomics 5, 36463653.

Edited by: H. J. Flint 